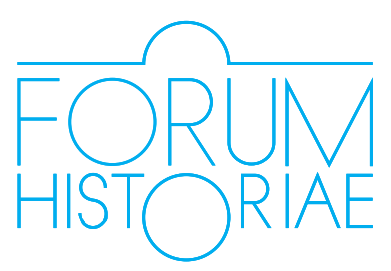

\title{
Vystúpenia z napoleonských vojen. Niekol'ko námetov na reflexiu
}

\author{
Marie-Pierre Rey
}

\begin{abstract}
:
REY, Marie-Pierre: Exiting the Napoleonic Wars. Some Ideas to Reflect Upon.

In the three sections of her article the author ruminates on the exiting of the Napoleonic Wars, which, through their geographic dimension, length, the use of new military technology and ideological content, brought important structural changes, and not only to French society. In the first section we learn about the diplomatic-military level of activity at exiting the War in 1814-1818, when France returned from the position of outcast to move back into the community of European states. However, the political exiting of the Napoleonic Wars was much more complicated and, in the author's opinion, was still not complete even by 1830. Probably the most complicated part of the process was related to military veterans, as Napoleon had made use of conscription, which impacted hitherto unseen numbers of common men - non-professional soldiers. Besides the huge loss of life, the veterans suffered from various trauma, grievances and injuries, which, however, society wanted to forget as quickly as possible.
\end{abstract}

Keywords: Napoleonic Wars, exiting wars, France, post-war society, veterans

$\mathrm{N}$ apoleonské vojny svojou dížkou (viac ako 15 rokov), geografickým záberom (od Španielska po Rusko), rastúcim používaním delostrelectva, masívnym využitím odvodu, dovtedy nevídaným zdokonal'ovaním vojenského velenia a silným ideologickým rozmerom priniesli európskym spoločnostiam a francúzskej spoločnosti zvlášt' zmeny každého druhu a neslýchaného rozsahu. Ako sa tej istej francúzskej spoločnosti podarilo prekonat' utrpenie, t’ažkosti a traumy spôsobené touto pätnást'ročnou vojnou? Akým spôsobom sa vystupovalo z konfliktu? V akej časovosti, v akom rytme a na akých politických, spoločenských a mentálnych základoch? Ako krajina nadviazala na „normálnost““ a o akú normálnost’ ide? Aby som našla odpoved' na tieto otázky, budem sa v prvej časti tohto príspevku zaoberat' vystúpením z vojny na diplomaticko-vojenskej úrovni v rokoch 1814 až 1818. Ide o najlahšie určitel'ný proces, lebo je zaznamenaný v diplomatických zmluvách a dokumentoch. Na politickej úrovni bolo vystúpenie z vojny dlhšie a menej jednoznačné, ako ukážem v druhej časti. Najzložitejšie a najbolestnejšie sa však ukázalo byt' na spoločenskej úrovni, a to bude predmet tretej časti tohto príspevku.

Vystúpit' z vojny na diplomaticko-vojenskej úrovni, 1814 - 1818: Francúzsko, od úlohy vyvrhel’a po návrat do spoločenstva európskych štátov

Rok 1814 bol prvým silným momentom vystúpenia z napoleonských vojen. Ked'že vojny cisárstva boli nerozlučne spojené s osobnostou Napoleona, jeho kariérou a osobnou mocou, vystúpenie z nich mohlo nastat’ len za cenu porážky 
cisára Francúzov. Po zvlášt' húževnatom francúzskom t’ažení, ktoré trvalo od januára do marca 1814, ${ }^{1}$ a po hrdinskej bitke o Paríž, ku ktorej došlo 30. marca, mal vstup koaličných vojsk do hlavného mesta Francúzska na druhý deň a z neho vyplývajúca okupácia za následok abdikáciu cisára Francúzov. Tá bola potvrdená zmluvou z Fontainebleau z 11. apríla 1814, ktorá bola výsledkom rokovaní medzi generálom Caulaincourtom, Napoleonovým vyslancom, a cárom Alexandrom I. Z finančného hl'adiska sa zmluva neskôr ukázala byt' pomerne vel'korysá voči cisárovi zbaveného trónu, ako aj voči jeho rodinným príslušníkom, no pokial' ide o politické hladisko, zakázala im akýkol'vek návrat do Francúzska s cielom zaručit' trvalý mier pre Francúzsko a Európu. 0 niekol’ko týždňov neskôr 30. mája 1814 (prvý) Parížsky mier oficiálne potvrdil vystúpenie vojny. Počas rokovaní, na ktorých sa tentoraz zúčastnili všetci členovia koalície, sa diplomatickí zástupcovia Ruska a Vel'kej Británie ukázali byt' zvlášt' zmierliví: z ich pohl’adu bolo síce dôležité, aby Francúzsko v budúcnosti nemohlo znova predstavovat' hrozbu pre európsky kontinent, nesmelo však byt' ani príliš oslabené: ako také by už nebolo schopné zohrávat' v Európe kl'účovú úlohu a spoluvytvárat' rovnováhu medzi jednotlivými štátmi tohto svetadiela. To bol dôvod pomerne zhovievavých opatrení voči Francúzsku.

Niektorí síce presadzovali návrat krajiny k hraniciam z roku 1790, Francúzsko však nakoniec získalo hranice, ktoré sa ukázali byt' výhodnejšie ako tie, o ktorých sa hovorilo v aprílovej dohode o prímerí: presahovali dokonca hranice z 1 . januára 1792, v porovnaní s ktorými krajina získala viac než 630 tisíc obyvatelov z celkového počtu 29 miliónov. ${ }^{2}$ Na severe sa francúzske obranné línie mierne vylepšili najmä pripojením miest Landau a Sarrebrücken. Krajina si okrem toho ponechala mestá Chambéry, Annecy a vel'kú čast' Savojska. Avignon a grófstvo Venaissin, Montbéliard a Mulhouse, ako aj viaceré malé nemecké enklávy v Alsasku zostali francúzske. Francúzsko prišlo o Flámsko a Luxembursko, ako aj o územia, ktoré Napoleon anektoval v Taliansku, Nemecku, Holandsku a Švajčiarsku. Anglicko však bolo nútené vrátit’ mu všetky jeho kolónie s výnimkou Tobaga, Svätej Lucie v Antilách, Isle de France (dnešný Maurícius) v Indickom oceáne a Malty. Na politickej úrovni Parížsky mier stanovil, že vo Viedni sa uskutoční generálny kongres, na ktorom sa vyriešia zatial' nedoriešené európske otázky, v prvom rade pol'ská. Nakoniec dokument obsahoval doložky, podla ktorých bolo Benátsko postúpené Rakúsku a prístav Janov Sardínskemu královstvu.

Podpísaný dokument sa teda javí ako kompromis medzi návratom $\mathrm{k}$ prirodzeným hraniciam, v ktorý dúfali Francúzi, a návratom k hraniciam z roku 1789, ktorý pôvodne plánovalo Prusko a Rakúsko. Zmluva nakoniec nestanovila nijaké vojnové reparácie, skoncovala s rekvizíciami a oslobodila väzňov: vd’aka týmto ustanoveniam sa mier, v ktorý francúzska spoločnost’ dúfala už mesiace, stal hmatatel'nou skutočnostou.

1 Pokial' ide o francúzske t’aženie, pozri najmä dve nedávno vydané diela: BOUDON, Jacques-Olivier. Napoléon et la campagne de France, 1814. Paris : Armand Colin, 2014; a REY, Marie-Pierre. 1814, un Tsar à Paris. Paris : Flammarion, 2014.

2 Porovnaj s WARSEQUIEL, Emmanuel de - YVERT, Benoît. Histoire de la Restauration. Paris : Perrin, 1996, s. 63. 
Mier podpísaný v Paríži čoskoro potvrdili a posilnili ustanovenia Viedenského kongresu. ${ }^{3}$ Cielom tohto kongresu ohláseného v zmluve z 30. mája 1814 bolo prekreslit' mapu Európy spochybnením väčšiny geopolitických zmien, ktoré sa zrodili z francúzskej revolúcie a cisárstva, a presadením iných zásad, v prvom rade bezpečnosti európskeho kontinentu a jeho rovnováhy. Konkrétne vo vzt’ahu k Francúzsku kongres potvrdil ustanovenia Parížskeho mieru týkajúce sa hraníc, zavádzal však aj nárazníkové štáty, ktoré mali „krotit'“ francúzsku hrozbu, držat' Francúzsko na uzde a obmedzit' jeho nebezpečnost'.

Spojenci sa síce v prípade Francúzska ukázali byt' jednomysel'ní a jednotní, no $\mathrm{v}$ d’alších otázkach čoskoro ukázali nezhody a rivalitu. Talleyrand, francúzsky minister zahraničných vecí, ktorý bol vo Viedni prítomný, šikovne a geniálne využil ich nezhody. ${ }^{4}$ Dňa 3. januára 1815 sa mu podarilo dosiahnut' podpísanie tajného obranného spojenectva medzi Francúzskom, Rakúskom a Anglickom, ktoré bolo v skutočnosti namierené proti Rusku a Prusku. Sotva za niekol'ko mesiacov sa táto koalícia roztrieštila napriek tomu, že bola ukutá v krvi vojenských t’ažení rokov 1812, 1813 a 1814, a zdalo sa, že z diplomatického hladiska Francúzsko opätovne získavalo výhodnejšie postavenie než štatút vyvrhel'a, ktorý mu pripísali spojenci. Úspech však trval len krátko, lebo s návratom Napoleona sa všetko opät' zmenilo: Sto dní totiž znovu utužilo spojencov proti cisárovi Francúzov vyhláseného za „nepriatel'a a narušitel’a svetového pokoja“. Konflikt sa obnovil a brutálne zavŕšil pri Waterloo.

Rokovania v roku 1815 sa ukázali byt' t’ažie než v roku 1814. Až do podpísania dohody v novembri 1815 vojvoda z Richelieu, ${ }^{5}$ bývalý generálny gubernátor Odeskej oblasti, ktorý bol stále blízky Alexandrovi I. a teraz ho král' L'udovít XVIII. dosadil na čelo vlády, vynakladal bezhraničné úsilie na to, aby od spojencov získal určité ústupky, a tým zmiernil osud krajiny. Robil to s podporou cára, ktorý bol od konca júna vo Francúzsku a počas pôsobivej vojenskej prehliadky vo Vertus 10. septembra demonštroval svoju moc a zároveň sa opätovne pokúsil umiernit' členov koalície. Už 7. júla Alexander I. zastával názor, že „s Francúzskom netreba zaobchádzat' ako s nepriatel'om. Mocnosti si v ňom nemôžu uplatňovat' svoje dobyvatel'ské práva." "Nechceli ho však vypočut': na jednej strane preto, že Rusi nebojovali pri Waterloo; a na druhej strane preto, že cára diskreditovala prehnaná, ba až naivná dôvera, ktorú vložil do Napoleona, ked' mu prepustil ostrov Elba. Predsa sa mu však podarilo dosiahnut' pre Francúzsko niekol'ko úprav: práve po jeho intervencii boli finančné sankcie znížené (z 800 na 700 miliónov frankov) a krajina neprišla o viac území. Cárovi totiž v roku 1815 rovnako ako v roku 1814 išlo o to, aby Francúzsku nebol nanútený príliš ponižujúci

\footnotetext{
3 Pokial' ide o Viedenský kongres a jeho novátorské zásady, pozri REY, Marie-Pierre. Le congrès de Vienne, un outil diplomatique à réhabiliter ? In Bulletin de l'Institut Pierre Renouvin, 2015/2 (č. 42), s. 21-32. Dostupné na internete https://www.cairn.info/revue-bulletin-de-l-institut-pierre-renouvin1-2015-2-page-21.htm. 4 Porovnaj WARESQUIEL, Emmanuel de. Talleyrand, le prince immobile. Paris : Texto, 2015, s. 634-636.

5 Pokial' ide o vojvodu z Richelieu, pozri passim biografiu, ktorú mu venoval WARESQUIEL, Emmanuel de. Le Duc de Richelieu, un sentimental en politique, 1766 - 1822. Paris : Perrin, 1990.

6 Pokial' ide o postoj cára k Francúzsku v roku 1815, pozri REY, Marie-Pierre. Alexandre Ier, le tsar qui vainquit Napoléon. Paris : Flammarion, 2013, s. 366-368.
} 
mier, ktorý by mohol znížit' dôveryhodnost' ešte krehkej královskej moci, obnovit' politickú neistotu a in fine destabilizovat' európsky kontinent, ktorému bol len teraz prinavrátený mier.

Druhý parížsky mier z 20. novembra 1815 teda obnovil hranice Francúzska z roku 1790 (ponechalo si Alsasko, Lotrinsko, Franche-Comté a Burgundsko, na ktoré si brúsilo zuby Prusko; zostal mu Avignon a grófstvo Venaissin, Montbéliard a Mulhouse), krajina však stratila viaceré strategické pevnosti, koloniálne územia a bola jej uložená finančná sankcia vo výške 700 miliónov frankov (čiže 140 miliónov ročne počas piatich rokov), z ktorých 137 neskôr použili na výstavbu pevností strážiacich jej vlastné hranice. Okrem toho muselo počas piatich rokov zniest' okupáciu svojich hraničných departmánov na severe a východe (spolu siedmich) vojenskou silou, ktorá sa odhaduje na viac ako 150 tisíc mužov. Náklady na okupáciu (ubytovanie, strava, starostlivost' o kone...), ktoré dosiahli 130 miliónov frankov ročne, boli v plnom rozsahu hradené z francúzskeho rozpočtu. Ročne tak počas piatich rokov krajina celkovo (reparácie a náklady na vydržiavanie okupačných vojsk) prišla o 270 miliónov, t. j. takmer o tretinu ročného rozpočtu Francúzska odhadovaného v tom čase na 600 miliónov, čo bola enormná suma.

V ten istý deň 20. novembra 1815 štyria spojenci nanovo vytvorenej koalície Vel'ká Británia, Rakúsko, Prusko a Rusko - slávnostne obnovili pakt uzatvorený v Chaumonte v marci 1814: bol to zrod Štvorspolku, ktorý si dal za prvoradý ciel' „dohliadat" na Francúzsko a zabezpečit', aby už nikdy nepredstavovalo nijakú hrozbu z geopolitického hladiska, a na tento účel zriadilo „konferenciu vel'vyslancov", ktorá sa konala dvakrát do týždňa v Paríži a jej úlohou bolo pozorovat' politický stav Francúzska a informovat' o ňom: kontrola krajiny bola teda zvlášt' ponižujúca a bolestná. Francúzsko nakoniec nebolo prizvané do Svätej aliancie, ktorú Alexander I. inicioval v septembri 1815: aj z tohto hladiska krajina stále zostávala vyvrhelom na medzinárodnej scéne.

Zostala ním až do jari 1819, ked' krajinu opustili posledné okupačné vojská, ktoré v nej ešte boli, ked’že francúzskemu štátu sa podarilo uhradit' reparácie vo výške 700 miliónov. V tomto období klúčového významu zohral vojvoda z Richelieu dôležitú úlohu tým, že postupne bojoval za konkrétne zlepšenie situácie krajiny. Od konca roku 1816 si stanovil za ciel' čo najrýchlejšie splatenie dlžnej sumy: išlo mu o to, aby čím skôr skoncoval s okupáciou, ktorá zruinovala rozpočet štátu i obcí a bola tažko znesitel'ná z hospodárskeho i psychologického hl'adiska napriek tomu, že Wellington, najvyšší velitel' okupačných vojsk, prísne dohliadal na to, aby sa nezvrhla, a vojská držal pevne na uzde. ${ }^{7}$ Vojvoda z Richelieu na tento účel v roku 1817 vyjednal pôžičku 200 miliónov frankov v londýnskej banke Bahring a v amsterdamskej banke Hope, ktorú chcel použit' na predčasnú úhradu splátok za roky 1819 a 1820. Ked'že členovia koalície mali v tejto situácii istotu, že reparácie budú zaplatené, v apríli 1817 sa vyslovili za zmiernenie okupačného mechanizmu (zníženie počtu mužov o 30 tisíc)

7 Pokial' ide o začiatky Reštaurácie, pozri prvé kapitoly dielo WARESQUIEL - YVERT 1996. 
a takmer o rok a pol neskôr v októbri 1818 na Aachenskom kongrese podpísali opätovné začlenenie Francúzska do európskej rodiny a úplné oslobodenie jeho územia zakotvené v dohovore z 9. októbra 1818. Francúzsky štát sa teda zbavil okupačných vojsk, vstúpil do Štvorspolku a hned' podpísal aj Svätú alianciu. V tento deň Francúzsko z diplomaticko-vojenského hladiska definitívne vystúpilo z vojny a v plnom rozsahu si znova našlo miesto v európskom geopolitickom spoločenstve.

Z politického hladiska sa veci ukázali byt' zložitejšie a zamotanejšie, lebo mier bol síce jednoznačne jadrom král'ových plánov, no otázka režimu, ktorý mal byt' nastolený, bola už menej jednoznačná.

\section{Vystúpit' z vojny z politického hl'adiska: aká „normalizácia“? Nezavŕšený proces $v$ roku 1830}

Aký režim treba ustanovit’ pre Francúzsko po ukončení cisárstva? A ako prekonat' cisárstvo bez ponorenia sa do občianskej vojny, rozdelenia a vášní, ktoré lomcovali Francúzskom 25 rokov? Odpoved' nebola samozrejmá na jar 1814 ani v zime 1815 - 1816 a prejavila sa mnohorakým tápaním.

Na jar 1814 bol síce Talleyrand rovnako ako Alexander I. naklonený skutočnému ústavnému systému, projektu, ktorý cár presadzoval u L’udovíta XVIII. počas ich stretnutia v Compiègne začiatkom mája, ${ }^{8}$ pre Ludovíta XVIII. však neprichádzalo do úvahy akceptovat' také obmedzenie jeho právomocí. Vo svojej deklarácii z 2. mája 1814 nazývanej „deklarácia zo Saint-Ouen“, ktorá poznačila jeho príchod do Francúzska, L’udovít XVIII. vyhlásil, že bol „privolaný spät' na trón svojich otcov z lásky k svojmu l'udu“, privolaný spät', a nie povolaný; Ludovítovi XVIII. síce nešlo o návrat k monarchii božieho práva, ale chcel zriadit' monarchiu, ktorá by sa dala nazvat' patriarchálnou. $V$ rámci logiky, ktorá chcela byt' logikou svornosti, 4. júna udelil svojim poddaným chartu. Charta bola síce Francúzom udelená v duchu odpustenia, no nezabúdala na nič z uplynulých rokov: král' ju datoval do 19. roku svojej vlády, čím vel'mi podráždil cára. ${ }^{9}$

Charta vychádzala zo zložitého hladania rovnováhy. Uznala určitý počet práv jednotlivcov a zásady zdedené z roku 1789 , medzi ktoré patrila sloboda svedomia, vierovyznania a tlače. Deklarovala občiansku rovnost' a rovnost' $\mathrm{v}$ oblasti daní a prístupu k verejných funkciám; zasadzovala sa za generálnu amnestiu (vrátane král'ovrahov z roku 1793) a nespochybňovala občiansky zákonník ani čestnú légiu (pričom však na lícovej strane medaily nahradila profil Napoleona profilom král'a Henricha IV.), ani výsady získané cisárskou šl'achtou; nepopierala predaj národného majetku. V nijakom prípade teda nešlo o návrat k zriadeniu

8 Porovnaj REY 2013, s. 354.

9 Porovnaj Alexandrovo vyhlásenie pre Hortenziu de Beauharnais citované v diele REY 2014, s. 188: „Svoje sklamanie opíše Hortenzii de Beauharnais takýmito slovami: »Onedlho prídem do Compiègne. Vidíte, že som smutný. Mám rád Francúzsko; želal by som mu štastie a vel’mi sa bojím, že táto rodina Bourbonovcov ho nedokáže zabezpečit'. Král' mi ukázal svoje vyhlásenie. Datuje ho do devätnásteho roku svojej vlády. Poradil som mu, aby tento dátum odstránil, ale nezdá sa, že by chcel moju radu poslúchnut'. Predpokladám, že bude šokovat' mnohé záujmy a že toto pre Francúzsko naozaj nie je vhodné. Bolí ma to, lebo sa zdá, že je to moje dielo.«" 
a spoločnosti Starého režimu. Nový predpis však obsahoval aj nejednoznačnosti: zároveň bola totiž obnovená šl'achta Starého režimu, katolicizmus sa opät' stal štátnym náboženstvom a vol'by už nemali byt' všeobecné, ale na základe cenzu založeného na majetku, čo bolo v rozpore so zásadou vzájomnej rovnosti občanov. Voličská základňa sa znížila na 100000 osôb, zatial' čo počet zvolitel'ných osôb neprekračoval 20000 potenciálnych kandidátov: išlo teda o vel'ké vzdialenie sa od rovnostárskeho ducha roku 1793 a zvrchovaný nebol národ ani l'ud. Bol čas na kompromisy a zmierenie, v júni 1814 bola väčšina štátnych úradníkov dosadených Napoleonom vyzvaná, aby slúžili novému režimu, a teda nenastal "hon na čarodejnice“, lebo kontinuita štátnej služby zvít'azila nad akoukolvvek inou logikou. Zároveň však nový režim zavrhol zhanobené symboly revolúcie: upustilo sa od trojfarebnej zástavy, král’ sa nazýval „král'om Francúzska, a nie králom Francúzov“, odteraz vládol „poddaným“, a nie „občanom“...

Po skončení Sto dní nebolo l’ahké zrealizovat' túto túžbu po kompromisoch, zmierení a pacifikácii presadzovanú v mene vyššieho záujmu krajiny. Poníženie, ktoré zažil král' nútený utiect' po oznámení Napoleonovho vylodenia, vrúcnost' l'udu, ktorá obkolesila nového cisára Francúzov po návrate z ostrova Elba, a spojenectvá, ktoré vyvolal - zdalo sa, že všetko dávalo za pravdu najzapálenejším rojalistom okolo grófa z Artois, ktorí po Waterloo znova získavali na sile. Podla nich - neskôr sa pre nich zaužíva výraz „ultrarojalisti“ - kompromis z roku 1814 znamenal len obrátenie sa proti autorite krála, a teda je potrebné zbavit’ krajinu s konečnou platnost'ou „jedu“ revolúcie, ako aj cisárstva. Ako vel'kí vítazi volieb v auguste 1815 (získali 350 kresiel z 398) ultrarojalisti čoskoro iniciovali zákonné čistky, ktoré v ovzduší násilia poznačenom rýchlymi popravami svedčili o vôli pomstit' sa, ktorá sa vel'mi líšila od ducha zmierenia presadzovaného králom rok predtým. Čistky v štátnej správe sa týkali viac ako štvrtiny úradníkov; zároveň bolo okolo 70 tisíc osôb zatknutých za „politický trestný čin“, 6000 z nich bolo odsúdených, z toho 300 až 400 na trest smrti: boli medzi nimi viacerí slávni generáli cisárstva, ktorí sa počas Sto dní spojili s Napoleonom, napríklad Mouton-Duvernet a Ney. Nakoniec v januári 1816 zákon proti král'ovrahom odsúdil na vyhnanstvo všetkých bývalých členov konventu (akými boli Carnot a David), ktorí odhlasovali smrt' Ludovíta XVI. Už teda nevládol duch amnestie a zmierenia. Postupom mesiacov si však král' uvedomil nebezpečenstvo, do ktorého tieto extrémne opatrenia viedli krajinu: totiž zatial’ čo Francúzsko bolo stále okupované a bolo potrebné pokúšat' sa dokázat' spojencom, že už nepredstavovalo zdroj destabilizácie v Európe, čistky a ovzdušie nejednoty, ktoré udržiavali, svedčili o opaku. Preto král' v septembri 1816 rozpustil ultrarojalistickú komoru a nastúpila umiernenejšia a liberálnejšia väčšina vedená vojvodom z Richelieu, ktorá, ako sme si ukázali, viedla k úspešným rokovaniam so spojencami. Od tohto dátumu až do roku 1820 prevládlo umiernenie a rovnováha a nový režim riadil logikou upokojenia a zmierenia. Proces bol však nad’alej krehký: vražda vojvodu z Berry v roku 1820, ideologické napätie režimu, ktoré z nej vyplynulo v tom istom roku a s vládou Karola X. od roku 1824 a napokon s revolúciou v júli 1830 ešte zosilnelo, všetky tieto po sebe idúce udalosti svedčili o tom, do akej 
miery politická normalizácia a zmierenie dvoch francúzskych štátov, jedného dediča Starého režimu a druhého dediča revolúcie a cisárstva, v roku 1830 ešte zd'aleka neboli zavŕšené.

Režimu Reštaurácie sa síce trvalo nedarilo presvedčit' francúzske obyvatel'stvo o svojej legitímnosti, účinnejšie však dokázal preukázat', že stelesňuje mier. Mier, v ktorý francúzska spoločnost', a dôverné správy prefektov cisárstva to otvorene zdôrazňovali, vel'mi dúfala od roku 1812. Dialo sa to však za vysokú cenu: cenu viac či menej dobrovol'ného a vedomého zabudnutia na vojnu a jej traumy, zatial' čo desat'tisíce vojakov a dôstojníkov, ktorí neštastne prežili napoleonské vojny, boli ponechané napospas svojmu osudu a trápeniam.

\section{Dobrovol’né zabudnutie?}

V napoleonských vojnách slúžilo vojenskej politike cisárstva a znášalo zvlášt' brutálnu vojenskú realitu približne 2,5 milióna mužov, z toho 1,66 milióna Francúzov. Vel'kú väčšinu z nich tvorili odvedenci, nie vojaci z povolania, a títo odvedenci boli hrou geopolitiky a Napoleonových ambícií vrhnutí s minimálnou, ba dokonca nijakou telesnou, psychologickou a duševnou prípravou do postupom rokov stále viac násilných a vražedných bojov: stačí spomenút' bitku pri Eylau alebo bitku na Berezine. Štatistiky vojnových obetí sa líšia, svedčia však o celom rozsahu strát.

Jacques Houdaille odhadol počet mŕtvych, Francúzov i cudzincov, na 870 tisíc. ${ }^{10}$ Iní historici, napríklad Jean-Paul Bertaud, uvádzajú trocha vyššie číslo, t. j. približne 970 tisíc mužov, z toho 633 tisíc Francúzov. Ďalšie odhady sa točia okolo 900 tisíc mužov za celé trvanie napoleonských vojen, čo by predstavovalo približne 40 až 45 \% celej francúzskej armády (na porovnanie uvádzam, že pri 8 miliónoch mobilizovaných počas 1 . svetovej vojny v rokoch 1914 až 1918 je tento podiel $25 \%$ ). Vidíme, do akej miery vojny cisárstva spôsobili francúzskej spoločnosti skutočné demografické krvácanie, ktoré malo citel’ný účinok na hospodársky vývoj Francúzska. Tieto konflikty dovedené na masovú úroveň však mali aj psychologický a sociálny vplyv.

Ako správne zdôraznila Natalie Petiteau vo svojom diele o Zajtrajškoch cisárstva (Lendemains d'Empire), „zatial’ čo spoločnost' 20. storočia venovala bývalým bojovníkom vel'kú pozornost', spoločnost' prvých dvoch tretín 19. storočia tento pojem prakticky nepoznala: voči týmto mužom..., ktorí sa vrátili domov po tom, čo riskovali svoje životy na bojovom poli..., režim nasledujúci po cisárstve neprejavil nijakú starostlivost'."11

V roku 1814 a ešte viac v roku 1815 chcel totiž režim Reštaurácie jednoznačne urobit' čiaru za napoleonskou minulostou a hrdinskou pamätou vojen cisárstva. ${ }^{12}$

10 Porovnaj HOUDAILLE, Jacques. Pertes de l'armée de terre sous le premier Empire, d'après les registres matricules. In Population, 1972/1, zväzok 27, s. 27-50.

11 PETITEAU, Natalie. Lendemains d'Empire. Les soldats de Napoléon dans la France du XIXème siècle. Paris : Boutique de L'Histoire, 2003, s. 89.

12 Literatúra, naopak, vzdialene odráža trpké osudy vojakov vel'kej armády, ktorí počas Reštaurácie upadli 
Bojovníkom cisárstva nebola postavená nijaká socha, nijaký pamätník. A až neskôr počas júlovej monarchie bol postavený prvý pamätník, zhodou okolností mramorová socha predstavujúca baróna Larreyho (vel'kého chirurga, vojenského lekára, ktorý však nebojoval) na nádvorí vojenskej nemocnice Val de Grâce.

Zároveň režim Reštaurácie zd’aleka nepomáhal bývalým bojovníkom cisárstva, ale sa vo vzt’ahu k nim ukázal byt' skôr podozrievavý (lebo im, koniec koncov často oprávnene, pripisoval bonapartistické cítenie) v čase, ked' bola celá francúzska spoločnost' naklonená viac tomu, aby obrátila list za dvadsiatimi piatimi rokmi revolučných a napoleonských vojen, než tomu, aby oslavovala odvahu svojich „hundrošov“. Preto na jednej strane došlo v rokoch 1815 - 1816 k demobilizácii a prepusteniu 300 tisíc vojakov, a na druhej strane sa objavil fenomén „polovičných žoldnierov“ - týmto termínom sa označovali bývalí vojaci a dôstojníci cisárstva, ktorí už poberali len polovicu žoldu, lebo neslúžili v král'ovskom vojsku a boli z neho vylúčení bud' preto, že boli oslobodení od vojenskej služby z dôvodu svojho telesného či duševného stavu, alebo preto, že boli podozriví z buričského politického cítenia. Zároveň títo poloviční žoldnieri (20 tisíc v roku 1815) podliehali prísnemu dohladu prefektov. Nemohli slobodne vykonávat' činnosti ani cestovat', potrebovali na to predchádzajúce povolenie; ich poštu otvárali a prípadne cenzurovali. No je pravda, že sa niektorým podarilo znova začat' civilný život a opätovne sa doň začlenit' tým, že sa oženili s vdovami alebo sestrami obchodníkov, sedliakov a remeselníkov, ktorí padli na fronte. Demografické krvácanie, ktoré sa dotklo mladých mužov, totiž prinútilo ich vdovy druhýkrát sa vydat' z rozumu. No mnohí z týchto bývalých bojovníkov, izolovaní, bez podpory rodiny, ktorým moc zakázala vrátit' sa do rodných dedín alebo miest zo strachu, že ich tam privítajú ako hrdinov a stanú sa buričskými osobnost’ami, tápali v biede a spoločenskom deklasovaní. S t’ažkostami prežívali a žili len v nostalgii Napoleonových hrdinských činov, ktorú si medzi sebou pestovali $\mathrm{v}$ úzkom kruhu vojenských kamarátov, v kaviarni, v bistre pri partii kariet alebo kociek. Dvakrát do roka si napriek zákazu obliekli pod obnosené plášte svoje uniformy, a to 15. augusta (dátum Napoleonových narodenín) a 2. decembra (výročie jeho korunovácie), a ako-tak sa usilovali prežit' vo vel'kej všeobecnej l'ahostajnosti.

Niesli si však v sebe mnohé traumy a mnohé utrpenia. Početné zle zhojené rany, ktoré boli stále bolestivé, postihnutia $\mathrm{v}$ dôsledku amputovaných chodidiel a odmrznutých rúk, hendikepy - mnohí bojovníci prišli o sluch či zrak - štatisticky zachytit’ tieto následky je síce tažké, no určité lokálne údaje poznáme: v departmáne Vaucluse, ktorý študovala Natalie Petiteau, 12 \% mužov, ktorí podali žiadost' o penziu, trpelo chronickou reumou „t'ažšou a predčasnou v porovnaní s väčšinou ich súčasníkov“ a „16 \% mužov sa vrátilo domov bez jednej končatiny. ${ }^{13} \mathrm{~K}$ týmto fyzickým ranám treba pridat' psychické traumy a neurózy. Historici prvej svetovej vojny tieto vážne poruchy dobre opísali, no

do zabudnutia. Pozri Balzacov román Plukovník Chabert a z novších diel novelu Josepha Conrada Duel, podla ktorej natočil Ridley Scott film nazvaný Súperi.

13 PETITEAU 2003, s. 108-109. 
historikom roku 1812 unikli: ked’že ich vtedy spoločnost' nebrala do úvahy ani ich neliečili zdravotníci, nebola o nich vypracovaná žiadna štúdia. Určité pramene však svedčia o úchylkách alebo samoničitel'skom správaní bývalých bojovníkov, najmä tých, ktorí prežili ruské peklo. Stéphane Calvet tak opísal jeden vel'mi jasný prípad vo svojich prácach o Napoleonových dôstojníkoch z departmánu Charente. V roku 1816 komisia, ktorá vyšetrovala jedného bývalého vojaka, na jeho adresu konštatovala, že upadol "do stavu demencie“, už nebol spôsobilý na službu a musel byt' hospitalizovaný. Doktor Esquirol, ktorý ho od konca roku 1816 pozoroval v nemocnici v obci Charenton, kde bol hospitalizovaný, dospel k záveru, že kapitán Jean-Antoine Gédéon de Chamborant bol „postihnutý neliečitel'nou duševnou chorobou spôsobenou zimou, ktorú zažil v Rusku“. „Každoročné správy psychiatra zdôrazňujú jeho »mizantropiu« a paranoju, ktoré sa z mesiaca na mesiac zhoršujú, jeho fóbiu z bielej farby, ktorú dávajú lekári do súvislosti so snehom v Rusku. " ${ }^{14}$ Zdá sa síce, že Esquirol takto správne vystihol traumu a jej pôvod, nepodarilo sa mu však zmiernit' utrpenie dôstojníka: ten po viacerých pokusoch spáchal v auguste 1824 vo veku 38 rokov samovraždu vyskočením z okna charentonskej nemocnice.

Zdá sa, že šialenstvo, beznádej a samovražedné sklony postihli mnohých mužov, ktorí sa vrátili do Paríža či Avignonu, a to v čase, ked’ francúzska spoločnost' už nechcela o týchto vojnách nič počut' a nezaujímala sa o tieto strašidlá, ktoré boli nositel'mi ich pamäti. Je pravda, že niektorí začínali svoje pamäti spisovat', no fenomén bol zatial' okrajový a v spoločnosti nemal vel'kú odozvu. Bolo treba skutočne počkat' až na návrat Napoleonových telesných pozostatkov v roku 1840 a neskôr na zavedenie medaily Svätej Heleny z iniciatívy Napoleona III. v roku 1857, ktorým štát konečne vzdal poctu starým „hundrošom“, ktorí ešte žili: až týmto oneskoreným zmierením medzi minulostou a prítomnostou sa napokon mohlo zavŕšit’ vystúpenie z 15 rokov trvajúcich napoleonských vojen.

Z francúzštiny preložila Kornélia Ševčíková

14 CALVET, Stéphane. Les officiers charentais de Napoléon au XIXème siècle. Destins de braves. Avignon : Rivages des Xantons et Université d'Avignon, 2010, s. 411.

Cituj:

REY, Marie-Pierre. Vystúpenia z napoleonských vojen. Niekol'ko námetov na reflexiu. In Forum Historiae, 2018, roč. 12, č. 2, s. 12-20. ISSN 1337-6861.

$\ldots$

Marie-Pierre Rey

Université Paris 1 Panthéon-

Sorbonne

UMR SIRICE

17 rue de la Sorbonne

75231 Paris cedex 05

mariepierre.rey@gmail.com 